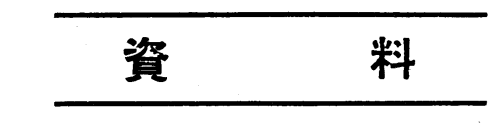

\title{
測光 法
}

正会員深尾保**香ノ木順平**

光束測定については螢光放電燈のこともまるので白熱 電球の場合のよ5には単純ではなく, いろいろの問題が せる.これについて最近広く取り岁げられている(1)ので これらについて考えてみたい。

\section{球形 光 束 計}

\section{球の理論}

光束測定用のウルブリヒト球の内面は, 次の三つの反 射特性さもたなけれればならない。

(1) 父射はなるべくランベルトの余弦法則に佂らこ と(出来るだけ完全搪散性で㚣ること)

（2）使用する波長籍明でスペクトル反射ができるだ け一樣であること(でき5るだけ光いこと）

(3) 反射率の高いこと

球形光束計では反射光による整面の輝度は， $\rho$ 起表面

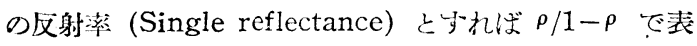
わされるが，実際にはこれを得ることは困踓でむり，た とえ，之れが得られても光源を入れる方法，支持物，遮 光板つために理諭とは少し違つてくる.

測光空に打いて一㴚な輝度が得られるよ5心，完全な 光束計では光源の位置はどこでもよいが，然際にはわず かに誤差がある。

球面の反射率が高いことは小さい光源の測光に重要で せり，遮光板，支持物があるための䛇美を小くする。し かしスペクトル特性の均一性からわずかにはずれている ことが強くきいてくるが，この久点は色フィルタを使え ば補償し得る。

\section{遮 光 板}

遮光板の位置は測光空の中心線上で光源からの距離の 1/3 の所がよく，板の大きさは光源のすべての点から测 光空のすべての部分さ遮光することが必要でせる。

球と光源の大きさとの関係は簡単にいえない，もし， 球の較正のための光束標淮電球が，测光すべき試験電球 と同じ型で普通の大きさのもので峞れば. 雨者の寸法の 関係は豃密起要しない，透明发るいは内面つや消白熱電 球の場合は直径 $7.6 \mathrm{~cm}$ までの光源では $1.52 \mathrm{~m}$ の球て

(1) *M. H. Gabriel, C. F. Koenig, E. S. Steeb, JR.; Photometry

Part I G. E. Rev. 54-9 (1951) 30 37

Part II G. E. Rev. 54-10 (1951) 23 29

**静网大学工学部
十分测れろ.これは比較的新しい, 派れていない電球の 場合に成り立つので，相当使つて黑化した電球では特別 の考虑起要する.

もし，正磼を覆したりあるいは標淮登と試験登との寸 法が似ていなかつたり，自己吸収性のものでせれば，吸 取に詨小る差について更正起要する。これには非常に安 定した光源を球の中心から離れた点に扤く．この光源か らの直射光が測光突にも試験燈標潐憕にも入らない上ら に遮光して乱き, 別の光源起点登し, 標潐燈だけはその 位罚におくが点燈しないままで, 測光空の輝度を測り， 再び試験登だけその位置において点登しないままで测 る.この雨方の测定值が等しければ二つの光源の吸収は 等しく，更正の必要がないが，等しくなければ標淮燈に 上る較正，若るいは試険登の測定には吸收についての二 つの測定值の比で適当な更正走する。

\section{スペクトル反射}

球形光束計の球面の整料に分光的に非選択性のものが なく，球の程算作用で少しのスペクトル反射の均一でな いことが程算されるので重要な問題になる．螢光登が用 いられるよらになつて，その特異なスペクトルのために 更に複雑になる。

非選択性の余料と賩淮視感度のフィルタがあれば完全 に要求志満し5るが，しかしこのよ5染塗料がないか ら塗布した球の特性坴求める必要が女る。

塗布面の標本でいろいろの滁料や塗布法さ分光分析し て比較するが，単なる反射率の測定では塗布球面の全体 の効果起示さない，そこで閉球内の任意の光源からのス ペクトル值を求め，これを反射性物質から離れた光束計 外で同一光源からのスペクトル值を求めて比較し, でき れば，白熱電球々昼光色螢光燈，あるいは青ガラᄎ球の 白熱電球を使ら之後者の二つは光源からの青の部分の光 を增して, 青の部分の塗料の吸収性を求めるのに確度が 高くなる．この力法を篮光燈測光用の球に用いるには, $40 \mathrm{~W}$ 昼光色罃光燈には 150 ～ $200 \mathrm{~W}$ のタングステン電 球がよい，分光器は球から受光器やフィルタを除いたつ や消ガラスの测光空からの拡散光がその入口のスリット に大るよらに装置する. 閉球状態で二光源のスペクトル 曲線を求め, 次に雨ランプを球から取り出して分光器を できるだけ大部分の光源を望久らるよらに持きスペクト 
ル曲線を求める. 二つのスペクトル曲線を波長毎に比較

して使用塗料のスペクトル選択性を求める.

二つのスペクトル曲線の比 $R_{\lambda}$ は $R_{\lambda}=E_{\lambda}$ in $/ E_{\lambda}$ out である. 但し, $E_{\lambda}$ in はランプの閉球内の場合の比スぺ クトル值， $E_{\lambda}$ out は同一ランプの同一波長での球外に 特け值である。

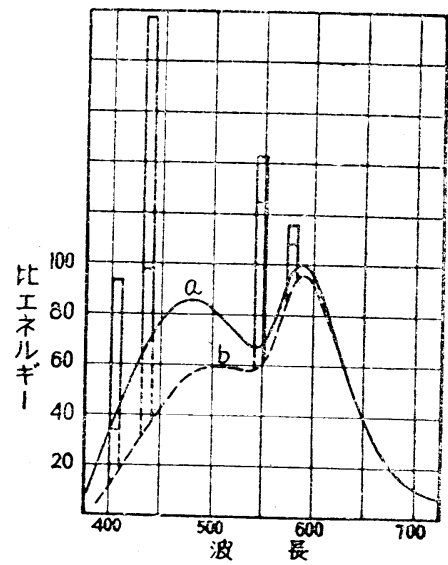

a： 底光色䖝光登のスペクトル分们浙線

b：同じ䖝光燈が球队で射を繰り返した堎合 第 1 网

昼光色篮光燈の球内球外に特忛るスペクトル分布曲線 は第1図の上5で，代表的な球の綜合答料避択度曲線は 第2図の上5で岕る. 各の球はその選执性が著しく違つ ていなくても等しくはないので，条について塗料の選択 既曲線范求める必要がある。

\section{測 光 空}

測光空は受光器に测るべき光束が入りざうすればいい ので，それ以上大きい必要はなく，直径 $7.6 \mathrm{~cm}$ の円形 空で十分である.

\section{球の構造}

球の材料には溥板金芑用いるが，合板で組立てると非

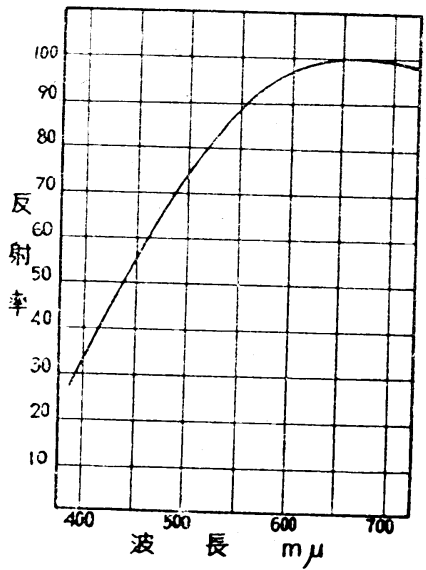

第 2 図代表的な球潅料の反射率曲線
常に軽い光束計が作られ, 大形の場合に都合よい, 值径 $5.17 \mathrm{~m}$ のものが NBS で用いら机ている.

\section{球面と塗装}

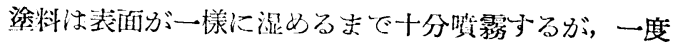
に多量相いて流れ山さない上5注意する。 1,000 W の乾

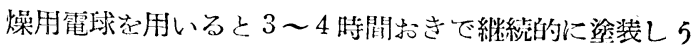

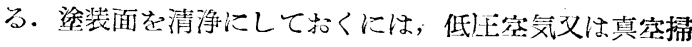
除器起ブロワーとして用いるのがよく，有でふきとると 面起隽める。

球の積算性を時々調査するには，フィラメントC 9 白 エナメル荃装の真究電球を用いる. 500 W A 19 型B電 球ならば申分ない。この電球球内に入れ口金を上にし て光束を测り次に口金忞下にして再び測る. 三つの場合 の読みの差が $3 \%$ 起越せ以゙再塗布の必要がある。 $3 \%$ と い5条件は淔接置換測光の埸合だけに限る。すふわち標

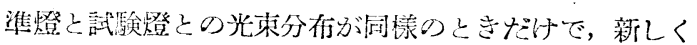

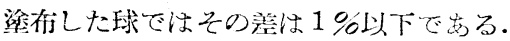

\section{物理測光器}

\section{現 況}

測光器としては光電池范使つたものでよく，そのスぺ クトル感度は色フィルタ虾用いて楞準視感度曲緗に合せ ることができる. $500 \Omega$ 㟧るいはそれ以下の通当な低抵

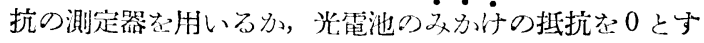
万電流平衡回路起胿いれ状，感度の比例性が非常によく

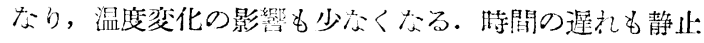
光源に対与る通常の測光には問题にならない. 买際测光 の場合に湖、万程度の照度に照射して起る一眭的の疲労 に対しては補傥しなければならないが,それには普通 30 分の間䀦があれば十分で岁る.しかし, 測光中連続的に 光電池起照射して何等の損伤もなく安定する。

\section{測光分光感度と視感度曲線}

光度計の感度性の視感度と同じでるる必要がある。 しかし, 球の塗装と受光器のスペクトル感度が視感度曲 線之完全に一致していないからフィルタ起要とする. ところか球塗料, 测光空, 受光器, フィルタを組合せて できるだけ視感度曲線に近ずけ得るフィルタが作られ た. このフィルタの一つは Corning 3304, Extra-dark Signal-yellow Shade, $74 \%$ standard thickness. \& 5 一つは Corning 3405, Meduim Blue-Green Shade, standard thickness である.この二川边は合せて值 筎に受光器の前に拉く.

球さ操作し初める前に受光器とフィルタの特性を試験 して, 球塗料を含めてできるだけ視感度曲線に合せるよ 5にする. 代表的な光度計の各部分の綜合分光感度と視 感度曲線之の比較を第 3 図に示小。 


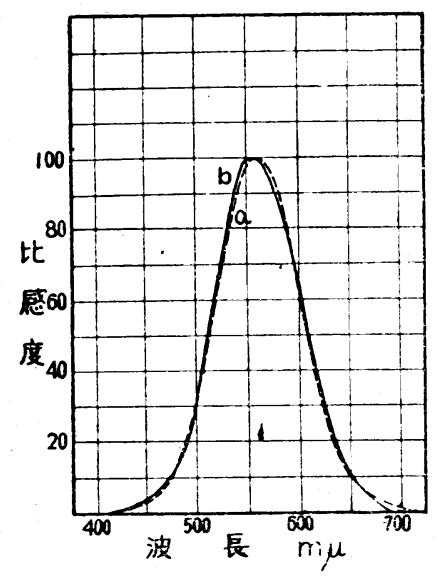

（a）綜合分光感度曲線 (b) 視感度曲線 第 3 図

\section{スペクトル感度の全計算と更正}

各の球形光束計のスペクトル選択度を決定すると，球 内に用いる各種の型の電燈について更生係数え用いれば 各部分の相異に対して補正することができる.女し，十 分に装置を選択寸机，光束計の各部分を完全に避択研 究しなくても，飽和した色を除いて誤差は $2 \%$ 以下にな るが，上い測光結果が得たいならこれらの部分の哭差に ついて考之なくてはならない，白熱電球の場合上りも篮 光登の測光の場合の方がより更正を要する。これは篮光 蹬では第 4 図の如く青の部分のエネルギーが大きいから である.白熱電球测光用の球では,標準登と試験燈とが同 じ型のものであれば更正の必要はない。

全装置に対して各波長に打ける有效係数を求めるには 光束計のすべての部分のスペクトル特性を知る必要がせ

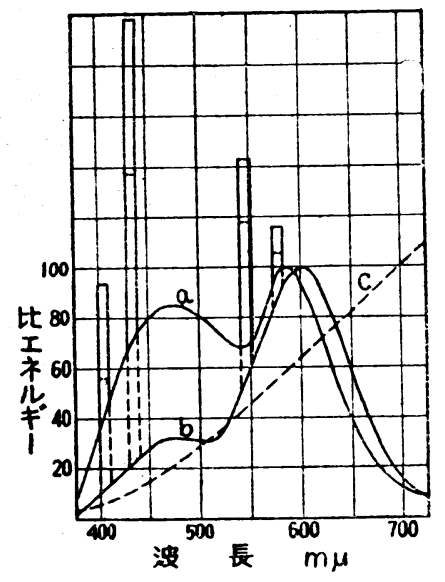

(a) 䝁光蛪 (day light)

(b) 䖝光燈 (soft white) (c) 白熱電球 符 4 図 スペクトル分布
ろ.この有効係数は球塗料のスペクトル選択度と受光器 のスペクトル感度及び更正用フィルタの透過率の皘であ る. 当実験室の方法では測光空の透過は別に取り报はな いで，自働的に球塗料の值の中に含まれている.

各波長についてのこれら三つの部分のスペクトル湘光 值の積が，これら三部分からなるこの光束計のその波長 に怙ける有效係数之なる。有效保数は波長の函数である から, その球内で測光するすべての光源のスペクトル特 性は, 白熱標準電球の場合と同樣に各波長について判つ ていなければならない，それでこの球形光束計のスぺ？ トル感度が視感度曲線に近似したものであるから，これ によつて篮光登に対する比を求めらる。

$$
\frac{\Sigma E_{F \lambda} \cdot S_{\lambda}}{\Sigma E_{F \lambda} \cdot \bar{y}}=R_{F}
$$

但し $S_{\lambda}$ : 任意の波長に括ける有效係数

$\bar{y}$ : 同じ波長の視感度曲線に特ける值 同樣に白熱標潐電球を用いる時は,

$$
\frac{\Sigma E_{W \lambda} \cdot S_{\lambda}}{\Sigma E_{W \lambda} \cdot \bar{y}}=R_{W}
$$

よつて白熱電球を標淮として篮光燈を测光するには,

$$
R_{W} / R_{F}=\text { 補正率 }
$$

㸃光燈の測光量の読みにこの綜合補正率をかければ正し い測光量が求められる。

(3)式で注意すべきことは白熱標準笪球と試験滥光燈 との組合せが違ら場合それらのスペクトル値の比がちが つているから暴なつた補正率を用いなければならない。

䖝光登測光の球形光束計で, $100 \mathrm{~W}$ の白熱電球を標準 として用いるときの代表的な補正率の值は第 1 表のよ 5 でせる。

第 1 裴

$100 \mathrm{~W} の$ 白熱電球を標準として用いた場合の球 形光束計による螢光登に対する更正

\begin{tabular}{l|c}
\hline \multicolumn{1}{c|}{ 光燈 型 } & 更 正 \\
\hline Std Warm White & $0.995_{5}$ \\
Std Cool White & $0.992_{5}$ \\
Day light & $0.989_{5}$ \\
\hline
\end{tabular}

\section{光 束 の 標準}

\section{単位の大きさ}

白金黑休放射体からの光は炭秝フィラメントの標準 電球と色は大して違つていない，炭素電球の色温度は約 $2,100^{\circ} \mathrm{K}$, 白金は $2,040^{\circ} \mathrm{K}$ で,この範囲の色では新しい 光度単位は IC 上り $1.9 \%$ 小さく，この差は被測定光源 の色温度が高くなれば少なくなる．結局現在のアメリカ のタングステン電球では光度標準が変つても実際には殆 
ど影響されず，どんな型の電球でも $1 \%$ 以上のちがいは ない.

\section{標準燈としての放電燈}

放電燈も測光標準に用い5るが十分に較正し，少なく とも 300 時間枯化し，働作が安定し，物理的外見のよい ものを用いる. 標準登としては白熱標準電球のよ5に常 に信頼が出来ず，また，值が一定でないことが主な欠点 でせる.たとえ注意しても光束の值は数\%も变化する。

しかし、・白熱電球と放電燈とでスペクトルの差がもる ために, 塗料, 受光器, フィルタの組合孔, 吸収性の差 について注意深く決定した上で放電燈を標準登として用 いる必要もある。

\section{水銀燈標準に和ける变化}

新しい国際協定に彷つて測光した場合，前述のよ5に 螢光登及び白熱電球ではその值が僅か違らのみであるが 水銀登では相当低いことが判つた，これは水銀登の光が 黃, 緑, 青, 紫艺含夕, 色合せが困覲で, 白熱標準電球 と直接に視感测光によつてはらまく测光できないためで せる.物理測光器が発蕉与れば，水銀登の測光は確度が ずつとよくなる。

\section{白秇電球の測光}

光電池を用いる多くの測定回路，特にここでのべる回 路は光束のわずかの变化にも非常に鋭敏でせり，また電 球の光度は電庄に大い、関係与るので，電源，電王调整， 测定器は全测定さ正確にするに重要心る要素で台る。

\section{電 源}

白熱電球では交流でも㨁流でも同じ電流值，光束值を 用いらることが奏験的こ判つている、調整，制御の点を は值流の方が交流より都合がよく、一般に萻電池嵓るい は電動発電機から供給する。なお，電王調整器には電子 管型のものがよい。

\section{予熱}

たとえ枯化した電球でも精密測定の前には短時間点登 する必要がある.7.5〜25 W の小型球は值ちに安定化す るが，大型球では 5 分以上かかる。たとえば奏験窒では $40 \mathrm{~W}$ 白熱電球は $1 / 2$ 分, $100 \mathrm{~W}$ 球は 1 分, $500 \mathrm{~W}$ 球は 2 分予熱をする。

\section{中間測定}

電球は寿命の途中で測光する必要がもる。黑化した電 球な球内で測光する場合は，吸収によつて測光空の照度 が低くなるので注意する必要が忠り，この光の提失は吸 取の補正方洼によろのがよい。

\section{螢光燈及びその他の放電燈の測光}

溃光燈及びその他の放電燈の測光は, 白熱電球の测光 とは大分異なつているので別々に取り扱ら必要がもる.
球形光束計を電燈の全光束の正確な測光に用いるが, 内面の桩散性, 遮光板の位置, 受光器, フィル夕測光窓 の綜合分光特性，球について十分な注意を必要とする.

球の大きさは勿論試験登の大きさに関係する.たと之 ば試験燈の長さは，球の内径の $85 \%$ より大きくてはな らない. 球は半球に開き5るよ5にし，ランプ特に溃光 燈を入れやすい構造にする。

篮光燈は普通水平の位置で測光し，水銀燈その他の型 のものはそれが設計された位置で測光する。

受光器, 湘光空, 色フィルタは白熱電球の測光の場合 用いると同じであるが但し白熱測光標準電球を較正に使 与場合には直流電源さ用い5る。

\section{器 具}

回路のランプ側，尔なわ台 2 次側の電庄計，電力評の 電圧コイルは高インピーダンスのものがよい，電源側， 与なわち 1 次側では，正しく計器の損失が計算され，更 正されれて和れば，低インピーダンス型のものでよい。経 験上 1 Vにつきインピーダンス $150 \Omega$ の電圧ュイルのも のなら，30W 岁るいはそれ以上の高ワットのランプに も十分でせる.高インピーダンスの電王コイルの計器も 必要で岕るがかよ5な計器は信頼度が低い。低ワット数 のランプは “Light restoration 法”で測定するか, Meter Amplifier をつけて測定する. 増幅器は電王計 霄力計の電生コイルと使らとき，波形を歪ませたり，位 相をずらせてはならない.ランプ電生又は電流を維持す ろために用いる測定器につけ加えて，一時に一つの測定 器を用いるべきで，このためには電王降下の低い開關器 厄゙計器回路を開閉する。

\section{Light Restoration}

電力計の電圧コイルは電力計がそのコイルェレメント の損失を測れるよ5に接続する. 回路の計器中で失われ る電力損は求めにくいが，この損失を求める最女良い方 法は，次の“Light Restoration Method”でせる。

ランプを規定の線路電玨で安定化し，回路には1 次側 に電珠計のみいれてランプの光束を記録し，次に(1)回 路に電力計をいれて読みとる.それから電在をあげてラ ンプの光束を前の值に合せ，(2)再びランプ電すを測定 す๖. 電生コイルの損失 $E^{2} / R$ t 2 回目の测定值から弓 き，もしこの更正した結果が更正しない初めの結果と一 致す机ば電力計は損失に対して少しも更正しないで用い 得る. 他の測定器の損失も同様の方法で決定し得る。

\section{增 幅 器}

增幅器には比較的高いインピーダンスの回路に精㴽な 低インピーダンスの電力計，電生計を使用しらることで まる. $2,000 \Omega$ 程度の低いインピーダンスの電生計及び 
電力計の電生コイルに入れて用い，確度 $0.1 \%$ の交流 電生計及電び力計溍通低インピーダンスで, フルスケ 一ルに 10 W も大力應要とするものがある．かよ5な 計器を高インピーダンスの回路に用いることは, 計器に 流れる電流によつて誤差杜生ずるから望ましくないそ れ故にこれら精密な計器を签光燈回路に用いるには，特 別の注意を必要となる。

Meter Matcher と精密な低インピーダンスの計器と を組合せるのが，滥光燈殊に低ワットのものの電気的特 性をきめる最も正確な方法で岁る。

\section{䨞 源}

電源は真に正嵫波で岁る必要がある。高調波が含まれ ていると测光つ結果に重大な影響が起る。電源は安定に し，できるたシけ急激な变化のないよ5にする。

電王調整の点でたとえ完全に満足なものでも， Static type の電生安定器は波形起ずまるので，フィルタ で波形の修正ができない限り，罃光燈回路に括いては正 確な計器の読みは得られない。

\section{槚準安定器}

Inductive type の安定器を標隼安定器として, 市販 の安定器や篮光登の試験に用いる標蕉として設計, 制作

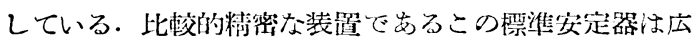
い範囲の働作電流に対してインピーダンスが一定で，㭙

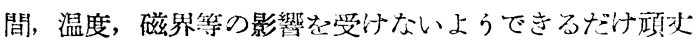
に作られているが，その取り扱いには注意を要する。

ランプの測光試験の場合は, 電源の電主々周波数とが

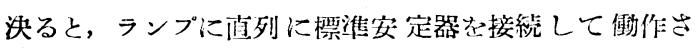
せ，それによつてランプ働作の種々の值を定める。安定 器の仕梯の場合は, 市販の安定器が標準安定器によると 同樣な特性を標準ランプに与えるよ5設計する。

\section{枯 化}

ガス放電燈は寿命特間のはじめに光束が急に隇少す る. 普通これはいくらか水銀が篮光体やガラスまるいは 両方に吸収されて行くために起る. 光束減少は 6〜8\% 程度で, 普通操作後 100 時間で落つくので, 安定化をは かるために 1.00 時間点燈後を以つて使用する.

\section{ランプ起動}

予熱型のランプはスイッチにより，手㗢で操作する. それにはランプの両端で口金ピンの各一つの間にスイッ チをいれ，スイッチには並列にコンデンサをいれるのが よい. $40 \mathrm{~W}$ 及びそれ吥のものでは $0.006 \mu \mathrm{F}, 85$ $100 \mathrm{~W}$ のものでは $0.05 \mu \mathrm{F}$ を用いる.予熱電流は予熱後 2 〜秒でランプ端部にグローを起させる程度が必要で むし，適当な予熱時間前に点燈したり，過大の電流で㝋 熱したりすると, ランプは Spiral したり, Hot spots
を作つたり，その他不適当な働作をする。

\section{Warm-up あるИは安定化操作}

枯化したランプでも短いWarm-up 岁るいは安定化 の期閪方必要でせる。普通小ざいランプでは6分，大き いランプでは 20 分かかる。ナトリウム登は例外で安定 化に少くと与 45 分かかる.

放電燈む球内で安定化するには，その放熱による球内

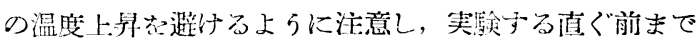

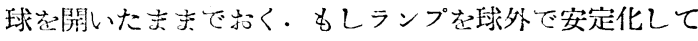
移少埸合は，ランプを迴転しないで安定化の期間と全く 同心゙位置に特くよ5にする・ナトリウム登では安定化の 後は動かしてはいけない。

\section{ランプの接続}

測定回路中のランプの位置は固定し，口金ピンに適当 な印をつけて接続する. Cross over. Parallel scheme の口金ピン揬続法が用いるられが(Cross over の方が好 ましい)，採用した方式はランプ 测定，枯化，寿命試験 中も弓続いて用いる. 推奖回路は第 5 图で岁る。

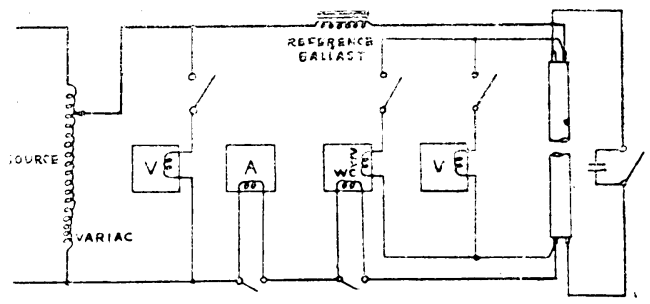

\section{周国温度}

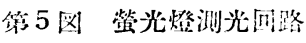

放電祭の光束, 電気的特性は, 周细温度, 通風状態の 影響をらけ, $24^{\circ} \mathrm{C}$ から $35^{\circ} \mathrm{C}$ の変化で約 $10 \%$ 位にな る. 測定の標淮温度は $27^{\circ} \mathrm{C}$ と考光られる. 周囲温度の 变動は $\pm 0.55^{\circ} \mathrm{C}$ の範囲内で, 通風はさけるる。

\section{Lapm Spiralling}

たとえ他の点ですべてが正しくても，ランプがらまく 働いていないと,正しい光束,電気的特性を決定するのに 相違を来方原因となる. Spiralling, Hot Spot, Swirls 等は普通見れば判る。しかし一見してわからない初期の Spiral には，かよらなランプに小さい永久磁石を沿わ せてゆくと，初期の Spiralling の方る点でもはつきり 輝いてくるので見えるよらになる．ランプを約 15 秒消 して再び点燈すればかよらなことはなくなる。

ランプが正しく働作していないと働作電圧，ワット数 の值が大きくなり，しかも多くの場合測定器に小さい動 摇が宓らわれる。

\section{結}

光源の光束を正確に決定する簡単な，しかも経費のか からない方法はいまだわかつていない（27-9-5 受付) 